\title{
Emmanuel Godo, Huysmans et l'évangile du réel
}

\section{Ida Merello}

\section{(2) OpenEdition}

\section{Journals}

\section{Edizione digitale}

URL: http://journals.openedition.org/studifrancesi/9320

DOI: 10.4000/studifrancesi.9320

ISSN: 2427-5856

\section{Editore}

Rosenberg \& Sellier

\section{Edizione cartacea}

Data di pubblicazione: 1 juin 2008

Paginazione: 220

ISSN: 0039-2944

\section{Notizia bibliografica digitale}

Ida Merello, «Emmanuel Godo, Huysmans et l'évangile du réel», Studi Francesi [Online], 154 (LII | I) | 2008, online dal 30 novembre 2015, consultato il 13 janvier 2021. URL: http://journals.openedition.org/ studifrancesi/9320 ; DOI: https://doi.org/10.4000/studifrancesi.9320

Questo documento è stato generato automaticamente il 13 janvier 2021.

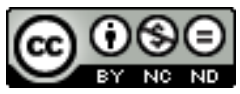

Studi Francesi è distribuita con Licenza Creative Commons Attribuzione - Non commerciale - Non opere derivate 4.0 Internazionale. 


\title{
Emmanuel Godo, Huysmans et l'évangile du réel
}

\author{
Ida Merello
}

\section{NOTIZIA}

emmanuel Godo, Huysmans et l'évangile du réel, Paris, Ed. du Cerf 2007, pp. 325.

1 L'A. propone una lettura unitaria dell'opera di Huys-mans, percorrendola dalle prime prove naturaliste fino ai romanzi della conversione, sulla base di alcuni assunti fondamentali. Innanzitutto, Huysmans non viene mai considerato uno scrittore dilettante neppure ai suoi inizi, e il suo accostamento al naturalismo di Zola e la partecipazione alle soirées di Médan sono spiegati come un avvicinamento a una scuola vicina al suo spirito, già autonomamente interessato agli aspetti grigi e disincantati del quotidiano degli umili. Il cambiamento introdotto da À rebours viene letto come la naturale prosecuzione della logica antiromanzesca di À vau l'Eau e En ménage, con la soppressione di ogni forma di azione. L'A. mostra come la rottura col naturalismo si realizzi attraverso un'opera che ne applica comunque i principi, anche se, nello stesso tempo, À rebours, per il fatto di essere il romanzo della singolarità di una coscienza, costituisce il rovescio del romanzo sociale. La scoperta dell'interiorità porta poi Huysmans sulla via dell'esoterismo e alla religione: l'A. vede nel percorso narrativo non solo la manifestazione di una quete spirituale, ma anche un mezzo per operare su se stesso, contribuendo alla costruzione della propria vita. Il saggio, di grande finezza di analisi e di piacevole lettura, si conclude con una breve antologia di frammenti tratti da alcune opere di Huysmans ed è corredato da una bibliografia. 